\title{
PENGARUH INHALASI SEDERHANA MENGGUNAKAN DAUN MINT (MENTHE PIPERITA) TERHADAP PENURUNAN SESAK NAPAS PADA PENDERITA TB PARU DI LINGKUNGAN UPT PUSKESMAS TANDANG BUHIT BALIGE
}

\author{
Haris Silitonga ${ }^{1}$, Corry Betti ${ }^{2}$, Theresa Sihombing ${ }^{3}$ Irma Simangunsong ${ }^{4}$ \\ Karmila Kaban ${ }^{5}$
}

1,2,3,4 Mahasiswa Fakultas Keperawatan dan Kebidanan UNPRI

Email : Silitongaharis@gmail.com

${ }^{5}$ Dosen Fakultas Keperawatan dan Kebidanan UNPRI

Email : Karmilakaban@ymail.com

\section{ABSTRACT : EFFECT OF SIMPLE INHALATION USING MINT LEAVES (MENTHE PIPERITA) ON THE REDUCTION IN SHORTNESS OF BREATH IN PATIENTS WITH PULMONARY TB IN THE UPT HEALTH CENTER TANDANG BUHIT BALIGE}

Background : Tuberculosis (TB) is an infectious disease that occurs due to bacteria that infect the lungs, namely Mycobacterium tuberculosis, an acidresistant bacterium, which spreads through droplets of people infected with TB bacilli. Patients with pulmonary TB have many diverse complaints which can cause breathing problems, namely shortness of breath which can cause ineffective airway clearance.

Purpose : To determine the effect of simple inhalation using mint (menthe piperita) on decreased breathlessness in pulmonary tuberculosis patients in UPT Tandang Buhit Balige Health Center in 2019 and there is a simple inhalation effect of mint leaves on reducing breathlessness in pulmonary TB patients.

Methods : Quantitative research with quasi-experiments. The population in this study were all patients with pulmonary TB in the UPT Puskesmas Buhit Balige, the number of samples in this study were 28 respondents. The intervention given was inhalation with mint leaves for 5 minutes. Before and after the action, check the breathing frequency and breathless scale.

Result :The majority of respondents who suffer from pulmonary TB in Buhit Public Health Center in Balige District are male, namely 67.9\%, Catholic Christians are $95.85 \%$, the average age is $41-50$ years, reaching $42.9 \%$, having the majority work with $39.3 \%$ and a smoking history of $71.4 \%$. The results of bivariate analysis with the T-Paired T-Test obtained sig. (2-tailed) 0,000 $<0.005$. So it can be concluded that there are differences before and after the simple inhalation of mint leaves.

Conclusion : that there is a simple inhalation effect of mint leaves on decreased breathlessness in pulmonary TB patients

Keywords : Simple inhalation, mint leaves, shortness of breath, Lung Tb

Haris Silitonga ${ }^{1}$, Corry Betti ${ }^{2}$, Theresa Sihombing ${ }^{3}$, Irma Simangunsong ${ }^{4}$, Karmila Kaban ${ }^{5}$

1,2,3,4 Mahasiswa Fakultas Keperawatan dan Kebidanan UNPRI. Email : Silitongaharis@gmail.com

${ }^{5}$ Dosen Fakultas Keperawatan dan Kebidanan UNPRI. Email : Karmilakaban@ymail.com 
INTISARI : PENGARUH INHALASI SEDERHANA MENGGUNAKAN DAUN MINT (MENTHE PIPERITA) TERHADAP PENURUNAN SESAK NAPAS PADA PENDERITA TB PARU DI LINGKUNGAN UPT PUSKESMAS TANDANG BUHIT BALIGE

Pendahuluan : Tuberculosis (TB) merupakansuatu penyakit yang menular terjadi karena bakteri yang menginfeksi paru-paru yaitu Mycobacterium tuberculosis, suatu bakteri tahan asam, penyebarannya dengan melalui droplet orang yang terinfeksi oleh basil TB. Pasien dengan TB Paru memiliki banyak keluhan yang bermacam-macam yang dapat menyebabkan permasalahan pada pernapasan, yaitu sesak napas yang dapat menyebabkan ketidakefektifan bersihan jalan napas.

Tujuan : Untuk mengetahuipengaruh inhalasi sederhana menggunakan daun mint (menthe piperita) terhadap penurunan sesak napas pada penderita TB Parudi lingkungan UPT Puskesmas Tandang Buhit Balige tahun 2019 dan terdapat pengaruh inhalasi sederhana daun mint dengan penurunan sesak napas pada pasien TB Paru.

Metode : Penelitian kuantitatif dengan kuasi eksperimen. Populasi penelitian ini merupakan seluruh penderita TB Paru di Lingkungan UPT Puskesmas Buhit Balige, jumlah sampel dalam penelitian ini yaitu 28 responden. Intervensi yang diberikan adalah inhalasi dengan daun mint selama 5 menit. Sebelum dan sesudah tindakan dilakukan pemeriksaan frekuensi pernapasan dan skala sesak napas.

Hasil: Mayoritas responden penderita TB Paru di Puskesmas Buhit Kecamatan Balige berjenis kelamin laki-laki yaitu $67,9 \%$, beragama Kristen katolik mencapai 95,85 \%, Berusia rata-rata 41-50 Tahun mencapai 42,9\%, memiliki pekerjaan mayoritas Petani dengan 39,3 \% dan memiliki riwayat merokok sebesar 71,4\%. Hasil analisa bivariat dengan uji T-Paired T-Test didapatkan nilai sig. (2-tailed) $0.000<0,005$. Dapat disimpulkan perbedaan sebelum dan sesudah inhalasi sederhana daun mint.

Kesimpulan : bahwa terdapat pengaruh inhalasi sederhana daun mint terhadap penurunan sesak napas pada pasien TB Paru

Kata Kunci : Inhalasi sederhana, daun mint, sesak napas, Tb Paru

\section{PENDAHULUAN}

Tuberculosis (TB) merupakan suatu penyakit menular yang terjadi karena bakteri yang menginfeksi paru-paru yaitu Mycobacterium tuberculosis, suatu bakteri tahan asam, penyebarannya dengan melalui droplet orang yang terinfeksi basil oleh TB (Black \& Hawks, 2014).

TB paru merupakan penyakit infeksi penyebab angka kematian dan angka kesakitan di seluruh dunia, tetapi setiap Negara berbeda angka kejadiannya.
TB Paru merupakan salah satu target dalam pencapaian Millenium Development Goals (MDGs) (Siswantoro, 2016). Menurut WHO (2014), penduduk dunia sudah mencapai 9,6 juta yang menderita TB Paru, dengan kasus terbanyak di Afrika (37 \%), Asia Tenggara (28\%), dan wilayah mediterania Timur (17 $\%)$. Di Indonesia, 3 wilayah terbesar penderita TB Paru adalah Sumatera (33\%), Jawa dan Bali (23\%), dan Indonesia bagian timur (44\%).

Haris Silitonga ${ }^{1}$, Corry Betti ${ }^{2}$, Theresa Sihombing ${ }^{3}$, Irma Simangunsong ${ }^{4}$ Karmila Kaban ${ }^{5}$

1,2,3,4 Mahasiswa Fakultas Keperawatan dan Kebidanan UNPRI. Email : Silitongaharis@gmail.com

${ }^{5}$ Dosen Fakultas Keperawatan dan Kebidanan UNPRI. Email : Karmilakaban@ymail.com 
Pasien TB Paru memiliki banyak keluhan yang bermacam-macam yang dapat menyebabkan permasalahan pada pernapasan, salah satunya dapat menimbulkan sesak napas karena terjadi penyumbatan saluran napas yang dikarenakan oleh kuman TB. Sesak napas pada pasien TB paru disebabkan oleh penderita penyakit TB paru yang sudah lanjut, yang infiltrasinya sudah sebagian dari paru-paru. Sesak napas itu sendiri adalah ketidakmampuan untuk membersihkan sekresi atau obstruksi dan saluran napas untuk mempertahankan bersihan jalan napas, dampak selanjutnya adalah meluasnya kerusakan pada parenkim paru apabila tidak segera menangani sesak napas (Siswantoro, 2016).

Diagnosa keperawatan yang timbul pada pasien dengan TB Menurut Back \& Hawks (2014) salah satunya yaitu bersihan jalan napas tidak efektif. Ketidakefektifan bersihan jalan napas merupakan dimana seseorang tidak mampu mengeluarkan secret dari saluran napas untuk mempertahankan kebebasan jalan napas (Amelia, Oktorina, Astuti, 2018).

Intervensi yang dapat dilakukan oleh seorang perawat berdasarkan NIC (2014) salah satunya ada kolaborasi dengan dokter dalam pemberian nebulizer. Nebulizer adalat suatu alat yang dapat digunakan untuk memberikan efek ringan terhadap respon batuk akan adanya lender/sekret pada saluran pernapasan (Anwari, 2019). Sedangkan untuk tindakan mandiri perawat dapat melakukan terapi komplementer berupa inhasasi sederhana tanpa menggunakan obat, namun dengan menggunakan bahan alami (aromaterapi) untuk mengatasi bersihan jalan napas.
Aroma terapi adalah suatu tindakan terapeutik. Salah satu aromaterapi yang sering dipakai adalah daun mint (Amelia, Oktorina, Astuti, 2018).

Inhalasi daun mint adalah inhalasi sederhana yang dapat digunakan dengan menggunakan waskom dengan air hangat yang dimasukkan beberapa lembar daun mint. Daun mint mengandung herbal aromatic yang memiliki sifat farmakologi yang digunakan sebagai obat tradisional. Daun mint mengandung menthol dan menunjukkan sifat anti bakteri dan anti virus serta efek antitusuf yang dapat memberikan efek relaksasi dan anti inflamasi serta menghambat hipersekrei lendir saluran napas, sehingga dapat meredakan status pernapasan pasien (Anwari, Olevianingrum, Fatmawati, 2019).

Inhalasi

sederhana

menggunakan daun mint dapat mengurangi sesak napas karena daun mint mengandung aroma menthol terdapat pada daun mint memiliki anti inflamasi sehingga dapat membebaskan saluran pernapasan (Jatiningsih, 2016). Daun mint dapat melegakan hidung sehingga membuat napas menjadi lebih mudah, selain itu dapat sebagai anastesi ringan yang bersifat sementara, kandungan vitamin A dan C, serta membantu mengobati flu dan menghentikan peradangan (Amelia, Oktorina, Astuti, 2018).

Hal ini sesuai dengan pelelitian yang dilakukan oleh Paraira et all (2013), dengan judul The effect of inhaled menthol on upper airway resistance in humans: A randomized controlled crossover study, di dapatkan hasil bahwa menthol atau mint dapat menurunkan dypnea atau sesak napas yang dilakukan

Haris Silitonga ${ }^{1}$, Corry Betti ${ }^{2}$, Theresa Sihombing ${ }^{3}$, Irma Simangunsong ${ }^{4}$ Karmila Kaban ${ }^{5}$

1,2,3,4 Mahasiswa Fakultas Keperawatan dan Kebidanan UNPRI. Email : Silitongaharis@gmail.com

${ }^{5}$ Dosen Fakultas Keperawatan dan Kebidanan UNPRI. Email : Karmilakaban@ymail.com 
pada 10 responden dengan gangguan saluran pernapasan atas.

Penelitian lainnya dilakukan oleh Ferari, Wulandari, dan Rakhmawati (2016), dengan hasil yaitu terdapat perbedaan tingkat kontrol asma sebelum dan sesudah dilakukan intervensi dengan nilai $p$ value 0,000 . Hal ini dapat disimpulkan bahwa inhalasi dengan menYaggunakan daun mint dapat menurunkan tingkat kontrol asma, hal ini dilihat dari perbedaan sebelum dan sesudahnya. Hal ini didukung oleh penelitian Siswantoro (2019), bahwa daun mint memiliki pengaruh terhadap penurunan sesak napas pada pasien penderita TB Paru dengan nilai $p$-value nya 0,000 $<$ 0,005. Jadi, tindakan inhalasi dengan menggunakan daun mint dapat menurunkan sesak napas.

Terapi inhalasi sederhana ini, dapat dijadikan sebagai tindakan mandiri yang dapat dilakukan oleh perawat di UPT Puskesmas Tandang Buhit Balige.

\section{METODE PENELITIAN}

Jenis penelitian ini yaitu kuantatif dengan quasi eksperiment. Pada penelitian ini ingin mengetahui pengaruh inhalasi sederhana daun mint terhadap penurunan sesak pada penderita TB Paru.

Populasi dalam penelitian ini yaitu seluruh pederita TB di UPT Puskesmas Tandang Buhit Balige. Pengambilan sampel atau sampling dengan menggunakan total sampling, yaitu teknik penetapan sampel dengan cara mengambil keseluruhan sampel dalam populasi (Nursalam, 2011).

Populasi penelitian ini adalah rata-rata 30 pasien / bulan pada tahun 2019. Jadi, jumlah sampel dalam penelitian ini yaitu 27,90 pasien, digenapkan menjadi 28 responden.

Selanjutnya

Peneliti menentukan subjek penelitian dengan teknik purposive sampel berdasarkan criteria inklusi yang telah ditetapkan. Peneliti kemudian akan memberikan pengrahan tentang penjelasan kepada responden tentang tujuan, manfaat, prosedur dan ketentuan-ketentuan pelaksanaan penelitian, lalu penliti meminta responden untuk menandatangani informed consent dan mengisi data demografi. Selanjutnya peneliti mengontrak waktu pasien selama 1 jam.

Kemudian peneliti mengukur derajat sesak napas pasien sebelum tindakan dengan menggunakan skala sesak napas Medical Research Council (MRS) dan frekuensi pernapasan. Kemudian dilakukan inhalasi sederhana daun mint selama 5 menit. Lalu dilakukan kembali pengukuran derajat sesak napas dan frekuensi pernapasan sesuai dengan SOP Inhalasi Sederhana Daun Mint yang diambil dari Penelitian Ningrum (2019). Sebelumnya Peneliti sudah melakukan uji etik dengan nomor: 005/KEPK/UNPRI/VI/2020.

\footnotetext{
Haris Silitonga ${ }^{1}$, Corry Betti ${ }^{2}$, Theresa Sihombing ${ }^{3}$, Irma Simangunsong ${ }^{4}$, Karmila Kaban ${ }^{5}$

1,2,3,4 Mahasiswa Fakultas Keperawatan dan Kebidanan UNPRI. Email : Silitongaharis@gmail.com ${ }^{5}$ Dosen Fakultas Keperawatan dan Kebidanan UNPRI. Email : Karmilakaban@ymail.com
} 
HASIL

Analisa Univariat

Tabel 1

Distribusi Frekuensi Responden Penderita TB Paru di UPT Puskesmas Buhit Balige Tahun 2020

\begin{tabular}{|c|c|c|c|}
\hline No & KarakteristikResponden & Frekuensi & Presentase (\%) \\
\hline \multirow[t]{8}{*}{1} & Jenis Kelamin & & \\
\hline & Laki-laki & 19 & 67.9 \\
\hline & Perempuan & 9 & 32.1 \\
\hline & Total & 28 & 100 \\
\hline & \multicolumn{3}{|l|}{ Agama } \\
\hline & Laki-laki & 19 & 67.9 \\
\hline & Perempuan & 9 & 32.1 \\
\hline & Total & 28 & 100 \\
\hline \multirow[t]{7}{*}{3} & \multicolumn{3}{|l|}{ Usia } \\
\hline & $<30$ Tahun & 0 & 0 \\
\hline & 31-40 Tahun & 5 & 17.9 \\
\hline & 41-50 Tahun & 12 & 42.9 \\
\hline & 51-60 Tahun & 10 & 35.7 \\
\hline & >60Tahun & 1 & 3.6 \\
\hline & Total & 28 & 100 \\
\hline \multirow[t]{6}{*}{4} & Pekerjaan & & \\
\hline & Wiraswasta & 9 & 32.1 \\
\hline & PNS & 2 & 7.1 \\
\hline & IRT & 6 & 21.4 \\
\hline & Petani & 11 & 39.3 \\
\hline & Total & 28 & 100 \\
\hline 5 & RiwayatMerokok & & \\
\hline & $\mathrm{Ya}$ & 20 & 71.4 \\
\hline & Tidak & 8 & 28.6 \\
\hline & Total & 28 & 100 \\
\hline & $\begin{array}{l}\text { Berdasarkan tabel } 1 \\
\text { en dalam penelitian ini } \\
\text { kan pasien dengan penderita }\end{array}$ & $\begin{array}{l}\text { Berusia } \\
\text { mencapai } \\
\text { pekerjaan }\end{array}$ & $\begin{array}{clr}\text { rata-rata } & 41-50 \text { Tahun } \\
42.9 & \%, \quad \text { memiliki } \\
\text { mayoritas Petani dengan }\end{array}$ \\
\hline alige & $\begin{array}{l}\text { di UPT Puskesmas Buhit } \\
\text { mayoritas berjenis kelamin }\end{array}$ & $\begin{array}{l}39.3 \% \\
\text { merokok s }\end{array}$ & $\begin{array}{l}\text { dan memiliki riwayat } \\
\text { ebesar } 71.4 \% \text {. }\end{array}$ \\
\hline
\end{tabular}

laki - laki yaitu $67.9 \%$, beragama Kristen katolik mencapai $95.85 \%$,

Haris Silitonga ${ }^{1}$, Corry Betti ${ }^{2}$, Theresa Sihombing ${ }^{3}$, Irma Simangunsong ${ }^{4}$ Karmila Kaban ${ }^{5}$ 1,2,3,4 Mahasiswa Fakultas Keperawatan dan Kebidanan UNPRI. Email : Silitongaharis@gmail.com ${ }^{5}$ Dosen Fakultas Keperawatan dan Kebidanan UNPRI. Email : Karmilakaban@ymail.com 
Analisa Bivariat

Tabel 2

Perbedaan Pre dan Post Frekuensi Pernapasan dan Skala Sesak Napas MRC pada Pasien TB Paru UPT Puskesmas Buhit Kecamatan Balige

\begin{tabular}{lllccl}
\hline No & Kategori & F & Mean & Std Deviation & $\begin{array}{l}\text { Sig } \\
\text { (2-tailed) }\end{array}$ \\
\hline 1. & $\begin{array}{l}\text { Pre test - Post test } \\
\text { Frekuensi }\end{array}$ & 3,964 & 1,774 & 0,000 \\
2. & $\begin{array}{l}\text { Pre test - Post test } \\
\text { Skala Sesak Nafas }\end{array}$ & 1,036 & 0,576 & 0,000 \\
& & & &
\end{tabular}

Berdasarkan tabel 2 dapat dijelaskan bahwa inhalasi sederhana daun mint berpengaruh terhadap penurunan sesak napas pada pasien TB Paru di UPT Puskesmas Buhit Kecamatan Balige, yang dapat dilihat dari hasil ujiT-Paired T-Test

\section{PEMBAHASAN}

Berdasarkan penelitian yang dilakukan dengan nilai sig. (2tailed) 0.000, dapat disimpulkan bahwa terdapat pengaruh inhalasi sederhana daunt mint terhadap penurunan sesak napas pada pasienpenderita penderita TB Paru di UPT Puskesmas Buhit Balige, yang dilihat dari perbedaan antara pretest dan post test frekuensi pernapasan dan skala sesak napas MRC.

Pada frekuensi pernapasan dan skala sesak napas MRC mengalami penurunan dan perbaikan. Hal ini sesuai dengan penelitian yang dilakukan oleh Anwani, Olevianingrum, dan Fatmawati (2019), bahwa nebulizer dengan menggunakan paper mint oil dan cairan nebule efektif digunakan untuk penanganan asma bronchiale. Sama halnya dengan TB Paru, pasien asma akan mengalami sesak napas. dengan nilai sig. (2-tailed) $0.000<$ 0,005 . Maka dapat disimpulkan bahwa terdapat pengaruh inhalasi sederhana daun mint terhadap penurunan sesak napas pada pasien TB Paru.

Hasil penelitian ini menunjukkan adanya perbedaan yang signifikan pada status batuk pasien yang meliputi frekuensi batuk, radang, wheezing, dan kemudahan keluarnya dahak setelah penambahan ekstrak mint melalui nebulizer.

Penelitian lain yang mendukung yaitu oleh Amelia, Oktorina, dan Astuti (2018), tentang aroma terapi peppermint terhadap masalah keperawatan ketidakefektifan bersihan jalan napas anak dengan bronkopneumonia, aroma terapi dilakukan selama 5-10 menit yang dilakukan selama 5 hari ternyata sangat efektif untuk mengurangi masalah bersihan jalan napas tidak efektif pada karakteristik sesak napas dan akumulasi sputum.

Penelitian ini didukung juga oleh Siswantoro (2018), bahwa dalam penelitiannya yaitu pengaruh

Haris Silitonga ${ }^{1}$, Corry Betti ${ }^{2}$, Theresa Sihombing ${ }^{3}$, Irma Simangunsong ${ }^{4}$, Karmila Kaban ${ }^{5}$

1,2,3,4 Mahasiswa Fakultas Keperawatan dan Kebidanan UNPRI. Email : Silitongaharis@gmail.com

${ }^{5}$ Dosen Fakultas Keperawatan dan Kebidanan UNPRI. Email : Karmilakaban@ymail.com 
aroma terapi daun mint dengan inhalasi sederhana terhadap penurunan sesak napas pada pasien tuberculosis paru dengan hasil $p$ value 0,008 yang artinya ada pengaruh intervensi tersebut terhadap nilai skala sesak napas pasien TB Paru.

Pasien dengan TB Paru akan mengalami peningkatan frekuensi pernapasan karena pasien TB terjadi penyumbatan saluran napas yang dikarenakan oleh kuman Mycobacterium tuberculosis yang menyebabkan obstruksi jalan napas yang selanjutnya akan menyebabkan kerusakan pada parenkim paru apabila sesak napas yang dialami tidak ditangani. Salah satu penanganannya adalah dengan menggunakan nebulizer / inhalasi, Inhalasi dengan daun mint dapat memberikan efek relaksasi pada otot polos trakea, serta memiliki efek antiin flamasi pada bronchitis kronis karena mengambat hipersekre silendir saluran napas, yang dapat membuka saluran pernapasan. Daun mint dalam bentuk ekstrak memiliki berbagai macam ester terutama menthylasetat dan monoterpene yang menghasilkan aroma dan flavor (minty) yang memanfaat untuk pernapasan. Menurut Koensoemardiyah dalam Amelia (2018) bahwa suatu bahan aktif yang terkandung dalam daun mint yaitumenthol, merupakan suatu senyawa organic yang dapat menghasilkan sensasi dingin pada saat diaplikasikan pada mulut atau kulit. Menthol merupakan sebagai bahan aktif utama dapat membantu melegakan saluran pernapasan seperti hidung sehingga membuat napas menjadi lebih mudah, dan berfungsi sebagai anastesi ringan, dan mengandung vitamin $A$ dan $C$ yang dapat mengobati flu dan menenangkan peradangan.

Selain itu, menurut Rasmin (2012), bahwa daun mint (peppermint) juga memiliki sifat anti bakteri yang akan melonggarkan bronkus sehingga melancarkan pernapasan. Terapiin halasi dengan peppermint (daun mint) yaitu ditujukan untuk mengatasi bronkospasme, mengencerkan sputum, menurunkan hiperaktivitas bronkus dan mengatasi infeksi. Karena kandungan pada daun mint tersebut dapat melegahkan pernapasan sehingga pasien dapat bernapas dengan mudah dan teratur, sehingga frekuensi pernapasan menjadi menurun dan stabil karena tidak ada sumbatan yang menghalangi pernapasan, dan dapat menurunkan skala sesak napas pasien menjadi lebih baik.

\section{KESIMPULAN}

Kesimpulan penelitian ini yaitu mayoritas penderita TB paru di UPT. Puskesmas Tandang Buhit Balige berjenis kelamin laki-laki yaitu $67.9 \%$, beragama Kristen katolik mencapai $95.85 \%$, Berusia rata-rata 41-50 Tahun mencapai $42.9 \%$, memiliki pekerjaan mayoritas Petani dengan 39.3 \% dan memiliki riwayat merokok sebesar $71.4 \%$.

Inhalasi sederhana daun mint berpengaruh dengan penurunan sesak napas pada pasien TB Paru di UPT Puskesmas Buhit Kecamatan Balige, yang dapat dilihat dari hasil ujiT-Paired T-Test dengan nilai sig. (2-tailed) $0.000<0,005$.

\section{SARAN}

Praktek Keperawatan

Tindakan intervensi inhalasi sederhana daun mint dapat dijadikan sebagai evidence based

Haris Silitonga ${ }^{1}$, Corry Betti ${ }^{2}$, Theresa Sihombing ${ }^{3}$, Irma Simangunsong ${ }^{4}$ Karmila Kaban ${ }^{5}$

1,2,3,4 Mahasiswa Fakultas Keperawatan dan Kebidanan UNPRI. Email : Silitongaharis@gmail.com

${ }^{5}$ Dosen Fakultas Keperawatan dan Kebidanan UNPRI. Email : Karmilakaban@ymail.com 
practice berupai ntervensi mandiri dalam mengatasi ketidak efektifan bersihan jalan napas pada pasien penderita TB Paru yang dapat dilakukan oleh perawat. Inhalasi sederhana juga dapat dijadikan intervensi yang dapat dilakukan di UPT. Puskesmas Tandang Buhit Balige yang dapat dibuat SOP agar dapat dilakukan oleh tenaga kesehatan di UPT puskesmas tersebut.

\section{Penelitian Selanjutnya}

Penelitian ini dapat dijadikan pedoman selanjutnya, dapat juga dimodifikasi dengan kelompok control dengan design penelitian yang lebih baik.

\section{DAFTAR PUSTAKA}

Amelia, Sherly., Oktarina, Rona., \&. Riko Astuti. (2018). “Aromaterapi Peppermint Terhadap Masalah Keperawatan Ketidakefektifan Bersihan Jalan Nafas Anak Dengan Bronkopneumonia." Research of Education and Art Link in Nursing Journal 1(2):77-83.

Anwari, Farida, Melawati Olevianingrum, Umi Fatmawati, Stikes Rs Anwar, and Medika Sidoarjo. (2019). "EFEKTIFITAS KOMBINASI MINT (PAPERMINT OIL) DAN CAIRAN NEBULIZER PADA PENANGANAN BATUK ASMA BRONCHIALE." Jurnal SainHealth 3(1).

Black, M.J. \& Hawk, H.J. (2014). Medical Surgical Nursing Clinic Management For Positive Outcomes. Volume 2. Australia: Elsevier

Brunner dan suddart. (2005). Buku
Ajar Keperawatan Medikal Bedah, Alih Bahasa, Yasmin Asih, EGC, Jakarta.

Jatiningsih, K. (2016). Pengaruh Senam Lansia Terhadap Tekanan Darah Pada Lanjut Usia Dengan Hipertensi Di Posyandu Lanjut Usia Di Desa Wotgaleh Sukoharjo, 11.

Koensoemardiyah. (2009).A-Z Aromaterapi Untuk Kesehatan, Kebugaran, danKecantikan. Yogyakarta : Andi Publisher

M. Bulechek, G. (2016). edisi enam Nursing interventions classification ( $\mathrm{N}$ I $\mathrm{C}$ ). singapore: elsevier Global rights

Ningrum, Eva Oktaviana. (2019). Pemberian Inhalasi Sederhana Dengan Daun Mint Untuk Mengatasi Masalah Ketidakefektifan Bersihan Jalan Nafas Pada An. X Di Kabupaten Magelang. Universitas Muhammadiyah Magelang: Magelang. KTI.

Notoatmodjo, S. (2010). Metodologi Penelitian Kesehatan. Jakarta: PT.Rineka Cipta.

NANDA (The North American Nursing Diagnosis Association). (2012). Nursing diagnostik: prinsip dan clasification 20122014. Phladelphia USA

Nursalam. 2008. Konsep dan penerapan metodologi penelitian keperawatan. Jakarta

Nursalam. (2011). Konsep dan penerapan metodologi penelitian ilmu keperawatan. Jakarta : Salemba Medika

Haris Silitonga ${ }^{1}$, Corry Betti ${ }^{2}$, Theresa Sihombing ${ }^{3}$, Irma Simangunsong ${ }^{4}$ Karmila Kaban ${ }^{5}$

1,2,3,4 Mahasiswa Fakultas Keperawatan dan Kebidanan UNPRI. Email : Silitongaharis@gmail.com

${ }^{5}$ Dosen Fakultas Keperawatan dan Kebidanan UNPRI. Email : Karmilakaban@ymail.com 
Price, S.A \& Wilson, L.M. (2005). Patofisiologis konsep klinis proses-proses penyakit. Edisi 6 volume 2. Jakarta: EGC

Rasmin, M, dkk. (2012). Prosedur tindakan bidang paru dan pernapasan diagnostik dan terapi. Jakarta: Bagian Pulmonologi FK UI. BalaiPenerbitanFK UI

Siswantoro, Edy. 2018. "Pengaruh Aroma Terapi Daun Mint Terhadap Penurunan Sesak Napas Pasien Tuberculosis Paru." Jurnal Keperawatan Dan Kebidanan Stikes Dlan Husada Mojokerto 49-56. WHO Global Report. (2011). Global Tuberculosis Control. WHO Library Cataloguing-in Publication Data.

Sugiyono. (2014). Metode Penelitian Pendidikan Pendekatan Kuantitatif, Kualitatif Dan $R \& D$. Bandung: Alfabeta.

Sugiyono.(2015). Metode Penelitian Tindakan Komprehensif. Bandung: Alfabeta 